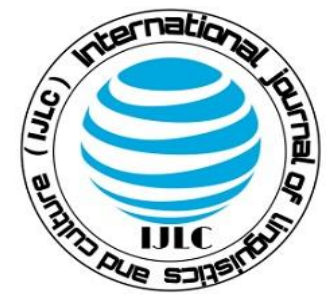
Volume \& Issues Obtainable at The Women University Multan
International Journal of Linguistics and Culture ISSN (Print): 2707-6873, ISSN (Online): 2788-8347
Volume 2, No.1, June 2021
Journal homepage: http://ijlc.wum.edu.pk/index.php/ojs

\title{
English and Chinese as a foreign language at institutional level in Pakistan: Teaching methods and Strategies
}

\author{
Aisha Ilyas \\ MPhil Research Scholar \\ Riphah International University, Faisalabad \\ Email: aishadameer786@gmail.com \\ Arslan Tahir \\ MPhil Research Scholar \\ Riphah International University, Faisalabad \\ Email: aslan_qureshi@live.com \\ Muhammad Ismail Tagga \\ Associate Professor of English \\ Emerson University, Multan \\ Email: ismailtagga@gmail.com
}

\begin{abstract}
The study focuses on discovering what approach Pakistani teachers are taking with regard to Chinese and English language teaching and can it promote language learning in the manner they teach? The current study explores numerous styles of teaching approaches and teaching techniques that Chinese and English teachers find to be successful in teaching a language class. This thesis primarily pursued quantitative analysis methodology. The survey approach was primarily used to gather data as defined and quantified by SPSS 23 statistical tools. In data analysis, the researcher uses descriptive statistics to examine and interpret results, obtained by questionnaires. This study's sample contained both Chinese and English students at the institutional level. In specific, for data gathering, a total of 80 respondents were approached from the Faisalabad district. The targeted respondents answered a questionnaire structured in the framework of the Likert scale. The results suggest that English students were considered to be active learners, whereas Chinese students deemed passive learners. This study demonstrates that institutes and organizations of Chinese and English languages need various modifications or changes, on applicable linguistic views regarding language instruction in Pakistan.
\end{abstract}

Keywords: FLT, teaching methods, teaching strategies, Chinese language, English language, 


\section{Introduction}

\subsection{Context of the study}

Teaching not only transmits information to learners but also helps students to compose expertly, to communicate competently, and to read easily. However, recent findings especially in rural contexts in Pakistan suggest that they have minimal command over language skills. It has been commonly accepted that if students are subjected to language learning activities, they will acquire authority over of their language skills (Paik, 2009). This brings one to ask whether teachers strive to build all the essential language skills in a comprehensive and coordinated manner. There are many local languages in Pakistan, including Punjabi, Saraki, Pashto, Brahvi, Baluchi, Persian, and Urdu. This multiculturalism may pose many difficulties, particularly for foreign language teachers. A multilingual class comprises elements including native language, mother tongue, and learner's official language (Malone, 2007). In the past, no study has been conducted to investigate the methods of Chinese and English in the foreign-language institutions in Pakistan (like their way of teaching or utilizing strategies). This study will focus on the different fields of integrated linguistic, teaching methods as well as contrasting Chinese and English language education in Pakistani background.

\subsection{English and Chinese language scope in Pakistan}

Many nations, such as Pakistan, have English as an official and standardized language traditionally. It is also recognized worldwide as strategic communication (Mesthrie). The English speaker is known to be a sorcerer in the current era (Simons \& Fennig, 2018). Today, English is the official language of Pakistan also plays an invaluable function in any area of existence (Canagarajah, 2013). English is used for study, literary purposes, often used in businesses and offices in Pakistan. English plays an essential function in Pakistan's educational hub. The educational association thus encourages the usage of English as a medium of communication. For international relations, thus, English is of great importance (Mastin, 2011). In reality, English speakers have more opportunities for the best employment in the public and private sectors of Pakistan. Similarly, society gives preference to English speakers over other language speakers (Khan, 2011).

Similarly, it is very simple to find a job in Pakistan, especially in Chinese companies, if you speak

Chinese. (Siddiqui, 2017). Pakistan is experiencing a severe economic downturn. Experts believe 
China Pakistan Economic Corridor would certainly improve the much-needed economic growth of the country (Ali, 2015). Many students from Pakistan learn Chinese more and more, especially after the CPEC project. China is an important market today, and corporate leaders are looking for people that can understand Chinese and function culturally well in China. (Abid, \& Ashfaq, 2015). International firms prefer to employ people who speak multiple languages. Young generation can study Chinese, in particular, so that entrepreneurial culture can be cultivated in Pakistan (Ali et al., 2018).

\subsection{Teaching Chinese \& English as a second or FL in Pakistan}

People have made considerable strides in learning Latin and French in the past in keeping with their origins and context, but Chinese and Chinese are now a comparatively new choice for many citizens around the world, especially Pakistan. In Pakistan, British and Confucius Institutes were set up to address the demands of citizens who want to study or learn English and Chinese. There are some existing and ongoing scholarly works on foreign language teaching/learning in Pakistan. Chinese Confucius Institutes are funded by Hanban, a Chinese Ministry of Education affiliate in Pakistan. But Confucius institutes do not appear to be self-governing and run in established universities, high schools, and colleges all over the globe, offering support, teachers, or educational materials.

Institutes are now collaborating with local host institutes and colleges, and expenditure is distributed between the Language Council and host organizations. For English, both CELTA and TESOL are the most popular academic credentials. CELTA is aligned with the University of Cambridge and TESOL is associated with Trinity College of London (Fauziati, 2010). There are also two wellknown Chinese language qualifications: the first one is YCT and the second one is HSK, affiliated with Huban (Chinese ministry). These language courses are designed to give adult learners the opportunity to teach Chinese and English to non-native students. They also discuss some of the problems affecting both instructors and learners in the classroom. However, once students take lessons of this type, they are well trained to begin their foreign language career as a Chinese / English teacher.

\subsection{Research questions}


1. What are the various pedagogical methods to teaching Chinese and English as a foreign language?

2. What teaching methods do they use in order to attract students' attention and interest?

3. What techniques and strategies do they perceive effective in teaching a foreign language class?

4. How should they interpret successful methods and tactics in conducting a foreign language lesson?

\section{Method}

\subsection{Research Design and Sampling}

The approach that has been primarily adopted in this analysis is quantitative research methodology. The survey approach was primarily used to gather the data in a manner that was both defined and quantified. The study began with basic quantitative correlation analysis to determine the composite variable and its individual variable indicators. The researcher chooses a simple random sampling technique for data collection. Therefore, the survey was conducted by sampling students who are learning English and Chinese in different institutions of district Faisalabad. However, the study was attended by a total of 10 institutions and 80 students (40 English and 40 Chinese) so, a total of eight students from each institution are chosen by the investigator.

\subsection{Instrumentation}

The formulation of research questions was therefore not a random and enlightened method, concentrating on the essence of the exploration's inquiry, purpose, and scope; close-ended questions were used for the collection of data. The researcher used questionnaires as a research tool. There are two sections of this instrument (questionnaire); there are six questions for each segment, and thus a framework focused on a total of eighteen questions. However, the students involve in the survey submitted their response by choosing the option they thought was the greatest fit for their answer. 
Hence, the responses differed from the minimum to the maximum, and the title included:

$\begin{array}{ll}\text { Range } & \text { Interpretation } \\ 0.00-1.00 & \text { Never } \quad \text { Very rarely } \quad\{\text { Negative Response }\} \\ 1.01-2.00 & \text { Rarely } \quad\{\text { Moderate Response }\} \\ 2.01-3.00 & \text { Occasionally } \\ 3.01-4.00 & \text { Very frequently }\{\text { Positive Response }\}\end{array}$

The instrument was designed by taking into consideration all the basic elements of teaching pedagogy for the instructor, such as teaching techniques and utilizing tactics when teaching students a foreign language.

- Piloting the Questionnaire

After the questionnaire was established, 10 respondents were viewed in such a way that their authenticity could be tested. However, the response of the respondents, the data obtained or its interpretation did not include in the (data collection, analysis) study. These 20 questionnaires were used to get feedback from the respondents if the statements/questions required some correction or rectification. It was found to be very useful in enhancing the legitimacy and usefulness of the chosen testing instrument as a questionnaire, which was then checked and updated according to the respondents' relevant proposals/recommendations. The most common reliability estimation tool has been used for the questionnaire, i.e. internal consistency tests. Cronbach's alpha was used to assess the consistency of the questionnaire used for this analysis.

\subsection{Data Collection Procedure}

The investigators surveyed the organizations and delivered the questionnaires to the selected respondents. Finally, the average response rate held 90 percent which was inspiring and motivating for the investigators. From a total of 100 questionnaires, 90 were back, but 10 questionnaires were not used for data processing due to certain vague responses. Therefore, eventually, 80 fully 
completed questionnaires were finalized for their analysis to produce the best possible reliable outcomes. This data collection process took approximately two months to identify the respondents, to perform the study, provide questionnaires and then get back the completed questionnaires from the respondents. Taking professional and cultural limitations into consideration, the researcher followed strictly the study's ethics.

\section{Data analysis}

\subsection{Questionnaire}

The data were evaluated descriptively using common statistical tools, SPSS-23, and each item's statistics were measured separately. The data was correct and deliberately entered, and a thorough exploratory data analysis (EDA) was carried out in advance. The data were considered to be usual and appropriate for further study. In order to achieve the required test results, frequency, accumulated percentage, standard deviation, mode, median, mean, and other essential descriptive statistics were used.

Table 1: Respondent's response frequency from the respondents (English and Chinese students)

for questions/statements related to teaching methods and strategies

\begin{tabular}{|c|c|c|c|c|c|c|c|}
\hline \multirow[b]{2}{*}{ Item/Domain } & \multirow[b]{2}{*}{ Feedback } & \multicolumn{3}{|l|}{ English } & \multicolumn{3}{|l|}{ Chinese } \\
\hline & & Frequency & Percentage & $\begin{array}{l}\text { Cumulative } \\
\text { Percentage }\end{array}$ & Frequency & Percentage & $\begin{array}{l}\text { Cumulative } \\
\text { Percentage }\end{array}$ \\
\hline \multirow[t]{2}{*}{ 1.Activities } & Never & - & - & - & 8 & 20.0 & 20.0 \\
\hline & Very Rarely & - & - & - & 13 & 32.5 & 52.5 \\
\hline \multirow{5}{*}{$\begin{array}{l}\text { Does your teacher use } \\
\text { activities like games, } \\
\text { storytelling, and role-play } \\
\text { when he starts the lesson? }\end{array}$} & Rarely & 6 & 15.0 & 15.0 & 14 & 35.0 & 87.5 \\
\hline & Occasionally & 11 & 27.5 & 42.5 & 5 & 12.5 & 100.0 \\
\hline & Very Frequently & 16 & 40.0 & 82.5 & - & - & - \\
\hline & Always & 7 & 17.5 & 100.0 & - & - & - \\
\hline & Total & 40 & 100.0 & & 40 & 100.0 & \\
\hline \multirow[t]{2}{*}{ 2. Audio visual aids } & Never & - & - & - & 1 & 2.5 & 2.5 \\
\hline & Very Rarely & - & - & - & - & - & - \\
\hline \multirow{5}{*}{$\begin{array}{l}\text { Does your instructor use } \\
\text { audio visual aids during } \\
\text { the lecture? }\end{array}$} & Rarely & - & - & - & - & - & - \\
\hline & Occasionally & 1 & 2.5 & 2.5 & 10 & 25.0 & 27.5 \\
\hline & Very Frequently & 18 & 45.0 & 47.5 & 20 & 50.0 & 77.5 \\
\hline & Always & 21 & 52.5 & 100.0 & 9 & 22.5 & 100.0 \\
\hline & Total & 40 & 100.0 & & 40 & 100.0 & \\
\hline \multirow[t]{2}{*}{ 3.Modern methodologies } & Never & - & - & - & 1 & 2.5 & 2.5 \\
\hline & Very Rarely & - & - & - & - & - & - \\
\hline \multirow{5}{*}{$\begin{array}{l}\text { Does your teacher use } \\
\text { modern teaching strategies } \\
\text { and methods? }\end{array}$} & Rarely & 8 & 20.0 & 20.0 & - & - & - \\
\hline & Occasionally & 7 & 17.5 & 37.5 & - & - & - \\
\hline & Very Frequently & 15 & 37.5 & 75.0 & 20 & 50.0 & 52.5 \\
\hline & Always & 10 & 25.0 & 100.0 & 19 & 47.5 & 100.0 \\
\hline & Total & 40 & 100.0 & & 40 & 100.0 & \\
\hline \multirow{6}{*}{$\begin{array}{l}\text { 4.Discussion method } \\
\text { Does your teacher use the } \\
\text { "Negotiation method" in } \\
\text { the class? }\end{array}$} & Never & - & - & - & 13 & 32.5 & 32.5 \\
\hline & Very Rarely & - & - & - & 18 & 45.0 & 77.5 \\
\hline & Rarely & 2 & 5.0 & 5.0 & 5 & 12.5 & 90.0 \\
\hline & Occasionally & 3 & 7.5 & 12.5 & 4 & 10.0 & 100.0 \\
\hline & Very Frequently & 18 & 45.0 & 57.5 & - & - & - \\
\hline & Always & 17 & 42.5 & 100.0 & - & - & - \\
\hline & & & 24 & & & & \\
\hline
\end{tabular}




\begin{tabular}{|c|c|c|c|c|c|c|c|}
\hline & Total & 40 & 100.0 & & 40 & 100.0 & \\
\hline \multirow[t]{2}{*}{ 5.Peer activities } & Never & - & - & - & 15 & 37.5 & 37.5 \\
\hline & Very Rarely & - & - & - & 21 & 52.5 & 90.0 \\
\hline \multirow{5}{*}{$\begin{array}{l}\text { Does your teacher } \\
\text { encourage peer group } \\
\text { activities? }\end{array}$} & Rarely & 2 & 5.0 & 5.0 & 4 & 10.0 & 100.0 \\
\hline & Occasionally & 7 & 17.5 & 22.5 & - & - & - \\
\hline & Very Frequently & 14 & 35.0 & 57.5 & - & - & - \\
\hline & Always & 17 & 42.5 & 100.0 & - & - & - \\
\hline & Total & 40 & 100.0 & & 40 & 100.0 & \\
\hline \multirow[t]{2}{*}{ 6.Teaching tools } & Never & - & - & - & - & - & - \\
\hline & Very Rarely & - & - & - & - & - & - \\
\hline \multirow{5}{*}{$\begin{array}{l}\text { Does your instructor use } \\
\text { only Chinese/ English, as a } \\
\text { medium of instruction } \\
\text { during delivering lectures? }\end{array}$} & Rarely & - & - & - & 9 & 22.5 & 22.5 \\
\hline & Occasionally & - & - & - & 21 & 52.5 & 75.0 \\
\hline & Very Frequently & 8 & 20.0 & 20.0 & 10 & 25.0 & 100.0 \\
\hline & Always & 32 & 80.0 & 100.0 & - & - & - \\
\hline & Total & 40 & 100.0 & & 40 & 100.0 & \\
\hline \multirow[t]{2}{*}{ 7.Problem solving } & Never & - & - & - & 5 & 12.5 & 12.5 \\
\hline & Very Rarely & 1 & 2.5 & 2.5 & 13 & 32.5 & 45.0 \\
\hline \multirow{5}{*}{$\begin{array}{l}\text { Does your instructor use } \\
\text { imaginary play, puppets, } \\
\text { stories, as a problem- } \\
\text { solving? }\end{array}$} & Rarely & 9 & 22.5 & 25.0 & 14 & 35.0 & 80.0 \\
\hline & Occasionally & 21 & 52.5 & 77.5 & 8 & 20.0 & 100.0 \\
\hline & Very Frequently & 7 & 17.5 & 95.0 & - & - & - \\
\hline & Always & 2 & 5.0 & 100.0 & - & - & - \\
\hline & Total & 40 & 100.0 & & 40 & 100.0 & \\
\hline \multirow[t]{2}{*}{ 8.Self-esteem } & Never & - & - & - & - & - & - \\
\hline & Very Rarely & - & - & - & - & - & - \\
\hline \multirow{5}{*}{$\begin{array}{l}\text { Does your instructor allow } \\
\text { pupils to ask more } \\
\text { questions? }\end{array}$} & Rarely & - & - & - & - & - & - \\
\hline & Occasionally & 2 & 5.0 & 5.0 & 1 & 2.5 & 2.5 \\
\hline & Very Frequently & 14 & 35.0 & 40.0 & 15 & 37.5 & 40.0 \\
\hline & Always & 24 & 60.0 & 100.0 & 24 & 60.0 & 100.0 \\
\hline & Total & 40 & 100.0 & & 40 & 100.0 & \\
\hline \multirow[t]{2}{*}{ 9.Drama techniques } & Never & 14 & 35.0 & 35.0 & 15 & 37.5 & 37.5 \\
\hline & Very Rarely & 14 & 35.0 & 70.0 & 21 & 52.5 & 90.0 \\
\hline \multirow{5}{*}{$\begin{array}{l}\text { Does your instructor use } \\
\text { the "Dramatizations" } \\
\text { method in the class? }\end{array}$} & Rarely & 10 & 25.0 & 95.0 & 1 & 2.5 & 92.5 \\
\hline & Occasionally & 2 & 5.0 & 100.0 & 3 & 7.5 & 100.0 \\
\hline & Very Frequently & - & - & - & - & - & - \\
\hline & Always & - & - & - & - & - & - \\
\hline & Total & 40 & 100.0 & & 40 & 100.0 & \\
\hline \multirow[t]{2}{*}{ 10. Improve abilities } & Never & - & - & - & 13 & 32.5 & 32.5 \\
\hline & Very Rarely & - & - & - & 14 & 35.0 & 67.5 \\
\hline \multirow{5}{*}{$\begin{array}{l}\text { Does your instructor } \\
\text { encourage daily base } \\
\text { newspaper reading to } \\
\text { enhance reading and } \\
\text { speaking skills? }\end{array}$} & Rarely & 3 & 7.5 & 7.5 & 13 & 32.5 & 100.0 \\
\hline & Occasionally & 3 & 7.5 & 15.0 & - & - & - \\
\hline & Very Frequently & 19 & 47.5 & 62.5 & - & - & - \\
\hline & Always & 15 & 37.5 & 100.0 & - & - & - \\
\hline & Total & 40 & 100.0 & & 40 & 100.0 & \\
\hline \multirow[t]{2}{*}{ 11.Motivation } & Never & - & - & - & 9 & 22.5 & 22.5 \\
\hline & Very Rarely & 1 & 2.5 & 2.5 & 10 & 25.0 & 47.5 \\
\hline \multirow{5}{*}{$\begin{array}{l}\text { Does your instructor use } \\
\text { lesser punishment and } \\
\text { more rewards strategies in } \\
\text { class? }\end{array}$} & Rarely & 3 & 7.5 & 10.0 & 9 & 22.5 & 70.0 \\
\hline & Occasionally & 18 & 45.0 & 55.0 & 7 & 17.5 & 87.5 \\
\hline & Very Frequently & 12 & 30.0 & 85.0 & 5 & 12.5 & 100.0 \\
\hline & Always & 6 & 15.0 & 100.0 & - & - & - \\
\hline & Total & 40 & 100.0 & & 40 & 100.0 & \\
\hline \multirow[t]{2}{*}{ 12.Humor } & Never & - & - & - & 10 & 25.0 & 25.0 \\
\hline & Very Rarely & 2 & 5.0 & 5.0 & 9 & 22.5 & 47.5 \\
\hline \multirow{5}{*}{$\begin{array}{l}\text { Does your instructor } \\
\text { provide a friendly } \\
\text { environment to the class? }\end{array}$} & Rarely & 17 & 42.5 & 47.5 & 11 & 27.5 & 75.0 \\
\hline & Occasionally & 14 & 35.0 & 82.5 & 10 & 25.0 & 100.0 \\
\hline & Very Frequently & 5 & 12.5 & 95.0 & - & - & - \\
\hline & Always & 2 & 5.0 & 100.0 & - & - & - \\
\hline & Total & 40 & 100.0 & & 40 & 100.0 & \\
\hline
\end{tabular}

The research findings are described in frequency Table 1. The findings indicate that $85 \%$ of English teachers have used exercises (activities) when they start their lesson in the class because they believe that Students should be able to participate and improve their talents, expertise, and understandings in numerous ways. Just $12.5 \%$ of Chinese teachers used skill development activities, so by 
comparing both the teachers' English teachers used activities very frequently. 100\% of English and 97.5\% of Chinese teachers used audio-visual aids in the class; therefore, it is evident that audiovisual aids are valuable resources for the learning process. 80\% of English teachers and 97.5\% of Chinese teachers use modern teaching methods and strategies in the class so, by comparing both of these, Chinese teachers very frequently use the latest approaches as compared to the English teachers. Further 95\% of English and 10\% of Chinese teacher use the discussion method in the class. 95\% of English and 0\% (Never, Very Rarely) of Chinese teachers encourage peer group activities in their class. 100\% of English and $77.5 \%$ of Chinese teachers use English as a classroom teaching tool. In order to teach problem-solving, $75 \%$ of English and 20\% of Chinese teachers use imaginative plays, drama, puppets, and narratives methods. Furthermore, talking about self-confidence in $100 \%$ of English and 100\% of Chinese teachers allow students to ask more questions. Just 5\% of English and 7.5\% of Chinese teachers use Dramatizations techniques in the class. Taking about skill enhancement, 92.5\% of English and 0\% (Never, Very Rarely) of Chinese teachers emphasize regular newspaper reading to improve their spoken skill. For enhancement of motivation level in students 90\% of English and 30\% of Chinese teachers use more rewards and lesser punishment techniques in the class. To build a friendly environment in the class 52.5\% of English and 25\% of Chinese teachers use humor in the class. By comparing both English and Chinese teachers English teachers are friendlier with the students that restrict the communication gap between them.

Results in Table (2a, 3a) present the results of all elements that collectively constitute the composite variable of teaching methodology and teaching techniques/strategies. The descriptive statistics display the number of cases or subjects $(\mathrm{N})$ of all items; absent and separately valid; Percentile (in quartile fashion), Mode (or the frequently occurring) for all the items, the Median (or middle) for all the items, average or Mean for each item, Skewness statistic, and the Std. Error of the Skewness, Std. Deviation (standard deviation), Maximum (highest) scores, and Minimum (lowest) scores of the items. The last series of results reveals that the $\mathrm{N}$ valid is 80 , which is the total number of respondents in this data file. Just these individuals were included in the $\mathrm{N}$ who did not leave missed data on any requested output variable. In order to evaluate the research data file, the mean series was put instead of missing values for permanent zero display e.g., no participant with missing details. All things (Mode, Median, and Mean) in Table (2a, 3a) tend to be fair or to the requirements expected by normality. Data analysis indicates that satisfaction of requirements (the details provided in the codebook and the researchers' interpretation of the variable) regarding the means are within ranges. 
For all variables, an acceptable range of Maximum and Minimum was deemed natural. Therefore no fault in the data was detected.

Table 2a: Data description: Univariate analysis (between English and Chinese respondents) of teaching methodology (Q 1-6)

\begin{tabular}{|c|c|c|c|c|c|c|c|c|c|c|c|c|c|}
\hline & & $: \stackrel{0}{:}$ & 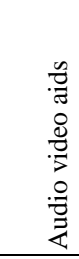 & 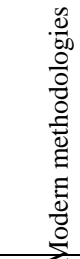 & 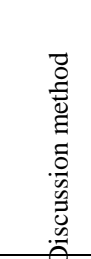 & 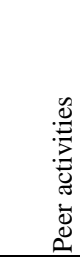 & 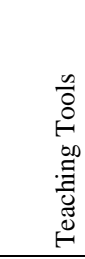 & : & $\begin{array}{l}\tilde{y} \\
\tilde{\pi} \\
0 \\
0 \\
0 \\
0 \\
0 \\
0 \\
0 \\
0\end{array}$ & 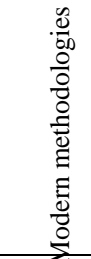 & 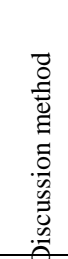 & 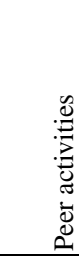 & 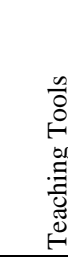 \\
\hline & & \multicolumn{6}{|c|}{ English } & \multicolumn{6}{|c|}{ Chinese } \\
\hline \multirow[t]{2}{*}{$\mathrm{N}$} & Valid & 40 & 40 & 40 & 40 & 40 & 40 & 40 & 40 & 40 & 40 & 40 & 40 \\
\hline & Missing & 0 & 0 & 0 & 0 & 0 & 0 & 0 & 0 & 0 & 0 & 0 & 0 \\
\hline \multicolumn{2}{|l|}{ Mean } & 4.60 & 5.50 & 4.68 & 5.25 & 5.15 & 5.78 & 2.40 & 4.88 & 5.38 & 2.00 & 1.73 & 4.03 \\
\hline \multicolumn{2}{|c|}{ Std. Error of Mean } & 5.00 & 6.00 & 5.00 & 5.00 & 5.00 & 6.00 & 2.00 & 5.00 & 5.00 & 2.00 & 2.00 & 4.00 \\
\hline \multicolumn{2}{|c|}{ Median } & 5 & 6 & 5 & 5 & 6 & 6 & 3 & 5 & 5 & 2 & 2 & 4 \\
\hline \multicolumn{2}{|l|}{ Mode } & .955 & .555 & 1.071 & .809 & .893 & .423 & .955 & .939 & .868 & .934 & .640 & .698 \\
\hline \multicolumn{2}{|c|}{ Std. Deviation } & .913 & .308 & 1.148 & .654 & .797 & .179 & .913 & .881 & .753 & .872 & .410 & .487 \\
\hline \multicolumn{2}{|l|}{ Variance } & -.208 & -.474 & -.350 & -1.110 & -.763 & -1.369 & .022 & -1.697 & -3.310 & .796 & .310 & -.034 \\
\hline \multicolumn{2}{|c|}{ Skewness } & .374 & .374 & .374 & .374 & .374 & .374 & .374 & .374 & .374 & .374 & .374 & .374 \\
\hline \multicolumn{2}{|c|}{ Std. Error Skewness } & 3 & 2 & 3 & 3 & 3 & 1 & 3 & 5 & 5 & 3 & 2 & 2 \\
\hline \multicolumn{2}{|c|}{ Range } & 3 & 4 & 3 & 3 & 3 & 5 & 1 & 1 & 1 & 1 & 1 & 3 \\
\hline \multicolumn{2}{|l|}{ Minimum } & 6 & 6 & 6 & 6 & 6 & 6 & 4 & 6 & 6 & 4 & 3 & 5 \\
\hline \multicolumn{2}{|l|}{ Maximum } & 4.00 & 5.00 & 5.00 & 5.00 & 5.00 & 6.00 & 2.00 & 4.00 & 5.00 & 1.00 & 1.00 & 4.00 \\
\hline \multirow[t]{3}{*}{ Percentiles } & 25 & 5.00 & 6.00 & 5.00 & 5.00 & 5.00 & 6.00 & 2.00 & 5.00 & 5.00 & 2.00 & 2.00 & 4.00 \\
\hline & 50 & 5.00 & 6.00 & 6.00 & 6.00 & 6.00 & 6.00 & 3.00 & 5.00 & 6.00 & 2.00 & 2.00 & 4.75 \\
\hline & 75 & 6.00 & 6.00 & 6.00 & 6.00 & 6.00 & 6.00 & 4.00 & 6.00 & 6.00 & 4.00 & 3.00 & 5.00 \\
\hline
\end{tabular}

Table 2b: Frequency table of teaching method for commutative / composite variable

\begin{tabular}{llll|llll}
\hline English & & & Chinese & & \\
\hline Valid & Frequency & Percent & $\begin{array}{l}\text { Cumulative } \\
\text { Percent }\end{array}$ & Valid & Frequency & Percent & $\begin{array}{l}\text { Cumulative } \\
\text { Percent }\end{array}$ \\
& & & 2.5 & 2.50 & 1 & 2.5 & 2.5 \\
4.17 & 1 & 2.5 & 5.0 & 2.67 & 1 & 2.5 & 5.0 \\
4.33 & 1 & 2.5 & 10.0 & 2.83 & 1 & 2.5 & 7.5 \\
4.67 & 2 & 5.0 & 25.0 & 3.00 & 6 & 15.0 & 22.5 \\
4.83 & 6 & 15.0 & 40.0 & 3.17 & 6 & 15.0 & 37.5 \\
5.00 & 6 & 15.0 & 60.0 & 3.33 & 8 & 20.0 & 57.5 \\
5.17 & 8 & 20.0 & 77.5 & 3.50 & 3 & 7.5 & 65.0 \\
5.33 & 7 & 17.5 & 97.5 & 3.67 & 7 & 17.5 & 82.5 \\
5.50 & 4 & 10.0 & 97.5 & 3.83 & 3 & 7.5 & 90.0 \\
5.67 & 2 & 5.0 & 100.0 & 4.00 & 2 & 5.0 & 95.0 \\
5.83 & 2 & 5.0 & & 4.33 & 2 & 5.0 & 100.0 \\
6.00 & 1 & 2.5 & & & & \\
Total & 40 & 100.0 & & & & & \\
\end{tabular}


Table 2c: Descriptive table of teaching method for commutative / composite variable

\begin{tabular}{|c|c|c|c|}
\hline \multicolumn{2}{|c|}{ Teaching method } & English & Chinese \\
\hline \multirow{2}{*}{\multicolumn{2}{|c|}{$\begin{array}{ll}\mathrm{N} & \text { Valid } \\
& \text { Missing }\end{array}$}} & 40 & 40 \\
\hline & & 0 & 0 \\
\hline \multirow{2}{*}{\multicolumn{2}{|c|}{$\begin{array}{l}\text { Mean } \\
\text { Median }\end{array}$}} & 5.1625 & 3.4000 \\
\hline & & 5.1667 & 3.3333 \\
\hline \multicolumn{2}{|l|}{ Mode } & 5.17 & 3.33 \\
\hline \multicolumn{2}{|c|}{ Std. Deviation } & .38395 & .40964 \\
\hline \multicolumn{2}{|c|}{ Variance } & .147 & .168 \\
\hline \multicolumn{2}{|c|}{ Skewness } & -.193 & .263 \\
\hline \multicolumn{2}{|c|}{ Std. Error of Skewness } & .374 & .374 \\
\hline \multicolumn{2}{|c|}{ Range } & 1.83 & 1.83 \\
\hline \multicolumn{2}{|l|}{ Minimum } & 4.17 & 2.50 \\
\hline \multicolumn{2}{|l|}{ Maximum } & 6.00 & 4.33 \\
\hline \multirow[t]{4}{*}{ Percentiles } & 25 & 4.8750 & 3.1667 \\
\hline & 50 & 5.1667 & 3.3333 \\
\hline & 75 & 5.3333 & 3.6667 \\
\hline & 100 & 6.0000 & 4.3333 \\
\hline
\end{tabular}

Figure 1: Histogram of teaching method with the normal curve for commutative / composite variable
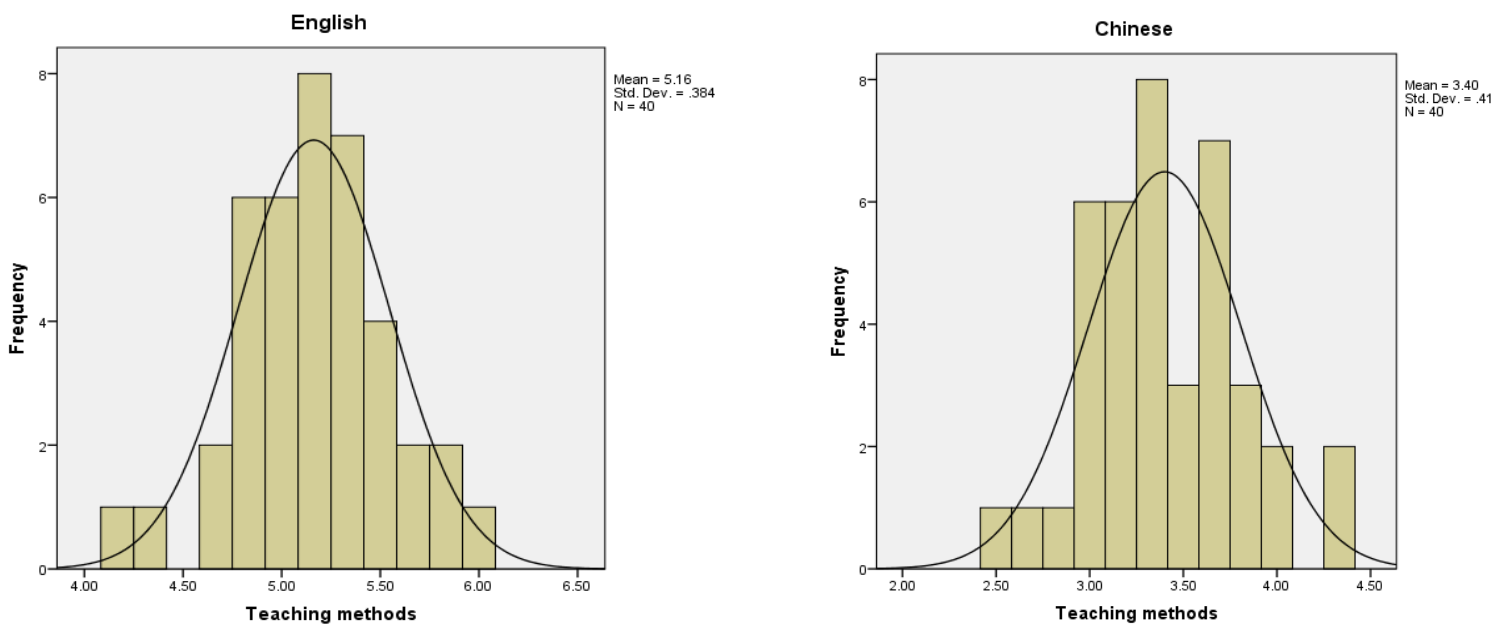
Table 3a: Data description: Univariate analysis (between English and Chinese respondents) of teaching strategies

(Q 7-12)

\begin{tabular}{|c|c|c|c|c|c|c|c|c|c|c|c|c|c|}
\hline & & 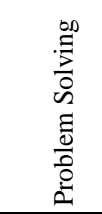 & 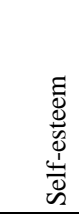 & 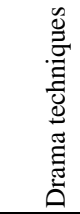 & 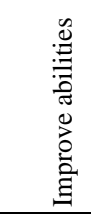 & 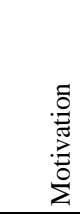 & 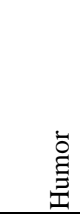 & $\begin{array}{l}\stackrel{0}{D} \\
\vdots \\
0 \\
0 \\
0 \\
0 \\
0 \\
0 \\
0\end{array}$ & 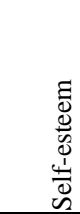 & $\begin{array}{l}\tilde{\Xi} \\
\stackrel{\Xi}{\Xi} \\
\tilde{\Xi} \\
\ddot{\Xi} \\
\tilde{\Xi} \\
\tilde{\Xi} \\
\tilde{\Xi}\end{array}$ & 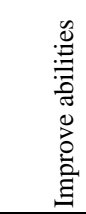 & 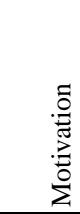 & 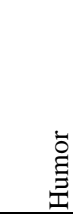 \\
\hline & & English & & & & & & Chine & & & & & \\
\hline \multirow[t]{2}{*}{$\mathrm{N}$} & Valid & 40 & 40 & 40 & 40 & 40 & 40 & 40 & 40 & 40 & 40 & 40 & 40 \\
\hline & Missing & 0 & 0 & 0 & 0 & 0 & 0 & 0 & 0 & 0 & 0 & 0 & 0 \\
\hline \multicolumn{2}{|l|}{ Mean } & 4.20 & 5.55 & 2.00 & 5.15 & 4.48 & 3.70 & 2.63 & 5.58 & 1.80 & 2.00 & 2.73 & 2.53 \\
\hline \multicolumn{2}{|c|}{ Std. Error of Mean } & 4.00 & 6.00 & 2.00 & 5.00 & 4.00 & 4.00 & 3.00 & 6.00 & 2.00 & 2.00 & 3.00 & 3.00 \\
\hline \multicolumn{2}{|c|}{ Median } & 4 & 6 & $1^{\mathrm{a}}$ & 5 & 4 & 3 & 3 & 6 & 2 & 2 & 2 & 3 \\
\hline \multicolumn{2}{|l|}{ Mode } & .791 & .597 & .906 & .864 & .933 & .939 & .952 & .549 & .823 & .816 & 1.339 & 1.132 \\
\hline \multicolumn{2}{|c|}{ Std. Deviation } & .626 & .356 & .821 & .746 & .871 & .882 & .907 & .302 & .677 & .667 & 1.794 & 1.281 \\
\hline \multicolumn{2}{|c|}{ Variance } & .275 & -.963 & .436 & -1.057 & -.123 & .653 & -.097 & -.800 & 1.268 & .000 & .265 & -.065 \\
\hline \multicolumn{2}{|c|}{ Skewness } & .374 & .374 & .374 & .374 & .374 & .374 & .374 & .374 & .374 & .374 & .374 & .374 \\
\hline \multicolumn{2}{|c|}{ Std. Error Skewness } & 3 & 2 & 3 & 3 & 4 & 4 & 3 & 2 & 3 & 2 & 4 & 3 \\
\hline \multicolumn{2}{|c|}{ Range } & 3 & 4 & 1 & 3 & 2 & 2 & 1 & 4 & 1 & 1 & 1 & 1 \\
\hline \multicolumn{2}{|l|}{ Minimum } & 6 & 6 & 4 & 6 & 6 & 6 & 4 & 6 & 4 & 3 & 5 & 4 \\
\hline \multicolumn{2}{|l|}{ Maximum } & 3.25 & 5.00 & 1.00 & 5.00 & 4.00 & 3.00 & 2.00 & 5.00 & 1.00 & 1.00 & 2.00 & 1.25 \\
\hline \multirow[t]{3}{*}{ Percentiles } & 25 & 4.00 & 6.00 & 2.00 & 5.00 & 4.00 & 4.00 & 3.00 & 6.00 & 2.00 & 2.00 & 3.00 & 3.00 \\
\hline & 50 & 4.00 & 6.00 & 3.00 & 6.00 & 5.00 & 4.00 & 3.00 & 6.00 & 2.00 & 3.00 & 4.00 & 3.75 \\
\hline & 75 & 6.00 & 6.00 & 4.00 & 6.00 & 6.00 & 6.00 & 4.00 & 6.00 & 4.00 & 3.00 & 5.00 & 4.00 \\
\hline
\end{tabular}

Table 3b: Frequency table of teaching strategies for commutative / composite variable

\begin{tabular}{|c|c|c|c|c|c|c|c|}
\hline \multicolumn{4}{|l|}{ English } & \multicolumn{4}{|c|}{ Chinese } \\
\hline Valid & Frequency & Percent & $\begin{array}{l}\text { Cumulative } \\
\text { Percent }\end{array}$ & Valid & Frequency & Percent & $\begin{array}{l}\text { Cumulative } \\
\text { Percent }\end{array}$ \\
\hline 3.17 & 1 & 2.5 & 2.5 & 2.00 & 1 & 2.5 & 2.5 \\
\hline 3.33 & 1 & 2.5 & 5.0 & 2.17 & 3 & 7.5 & 10.0 \\
\hline 3.50 & 1 & 2.5 & 7.5 & 2.33 & 4 & 10.0 & 20.0 \\
\hline 3.67 & 5 & 12.5 & 20.0 & 2.50 & 6 & 15.0 & 35.0 \\
\hline 3.83 & 3 & 7.5 & 27.5 & 2.67 & 3 & 7.5 & 42.5 \\
\hline 4.00 & 7 & 17.5 & 45.0 & 2.83 & 5 & 12.5 & 55.0 \\
\hline 4.17 & 7 & 17.5 & 62.5 & 3.00 & 5 & 12.5 & 67.5 \\
\hline 4.33 & 5 & 12.5 & 75.0 & 3.17 & 4 & 10.0 & 77.5 \\
\hline 4.50 & 4 & 10.0 & 85.0 & 3.33 & 3 & 7.5 & 85.0 \\
\hline 4.67 & 2 & 5.0 & 90.0 & 3.50 & 2 & 5.0 & 90.0 \\
\hline 4.83 & 2 & 5.0 & 95.0 & 3.67 & 2 & 5.0 & 95.0 \\
\hline 5.00 & 1 & 2.5 & 97.5 & 4.00 & 2 & 5.0 & 100.0 \\
\hline 5.17 & 1 & 2.5 & 100.0 & Total & 40 & 100.0 & \\
\hline Total & 40 & 100.0 & & & & & \\
\hline
\end{tabular}


Table 3c, Descriptive table of strategies method for commutative / composite variable

\begin{tabular}{|c|c|c|c|}
\hline \multicolumn{2}{|c|}{ Teaching strategies } & English & Chinese \\
\hline $\mathrm{N}$ & Valid & 40 & 40 \\
\hline & Missing & 0 & 0 \\
\hline $\mathrm{Me}$ & & 4.1458 & 2.8750 \\
\hline $\mathrm{Me}$ & & 4.1667 & 2.8333 \\
\hline Mo & & $4.00^{\mathrm{a}}$ & 2.50 \\
\hline Std & & .44045 & .50742 \\
\hline Val & & .194 & .257 \\
\hline Ske & & .133 & .415 \\
\hline Std & vness & .374 & .374 \\
\hline Rar & & 2.00 & 2.00 \\
\hline Mil & & 3.17 & 2.00 \\
\hline $\mathrm{Ma}$ & & 5.17 & 4.00 \\
\hline & 25 & 3.8333 & 2.5000 \\
\hline & 50 & 4.1667 & 2.8333 \\
\hline & 75 & 4.4583 & 3.1667 \\
\hline & 100 & 5.1667 & 4.0000 \\
\hline
\end{tabular}

Figure 2, Histogram of teaching strategies with the normal curve for commutative / composite variable
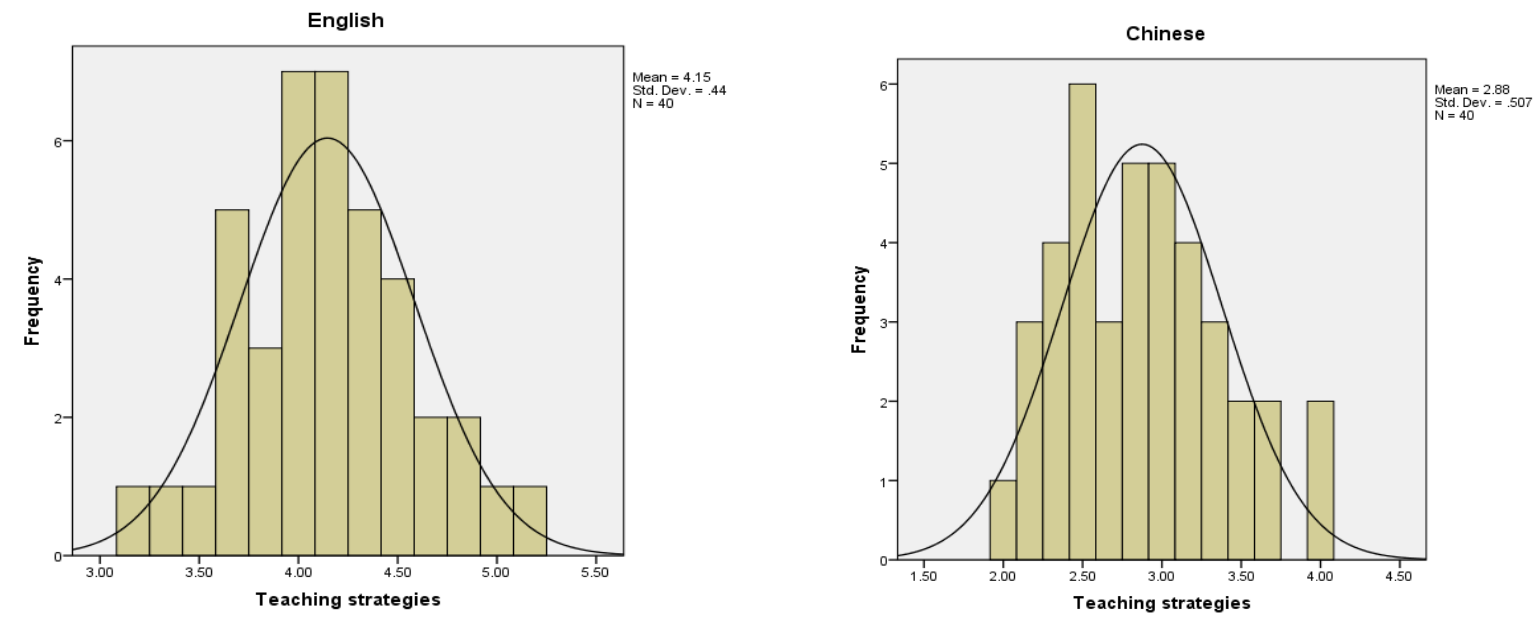

\section{Discussion}

The findings were compatible with the study's aims to define teaching methods and teaching strategies utilized by an instructor in instructional and studying a foreign language class. 


\subsection{Findings}

The aim of the discussion is to explain and illustrate the significance of the results. The key aim of the research was to explain the instructional methods and techniques utilized by an instructor to teach a foreign language (English / Chinese) class. Thus results were presented in relation to the study's goals as follows:

- The data obtained reveal that English teachers use ability building exercises most of the time as compared with Chinese teachers. English instructor has been more involved and teaches students about the empathy and understanding of different perspectives.

- To make class more interactive or interesting and to retain learners' attention, audio visual aids are the considered most important part of the class by both of the teachers.

- English and Chinese teachers rely both on conservative and inclusive educational methods and they concentrate primarily on the requirements of particular students than on pretending that all students have the same degree of comprehension.

- For interactive sharing of ideas between a teacher and students or among students in order to promote students' thought, learning, problem-solving, comprehension, or literary appreciation, the discussion method is considered as a backbone for an English instructor.

- English teachers use peer group activities more often compared with Chinese teachers since students who operate in pairs and communities usually do well on assessments including logic and logical thought.

- Most of the time Chinese teachers use English from the beginning of a course as the main language in class because English is the official language in Pakistan most of the learners don't understand Chinese on their first day at class. On the other hand, English teachers utilize English as a means of teaching for greater comprehension of English content as well as the availability of improved curricula, better work and career growth prospects, constructive impact on the broader population, and broader networking opportunities.

- Compared to Chinese teachers, English teachers use more brainstorming and team problemsolving techniques as problem-solving.

- In order to improve interactive debates, both English and Chinese teachers encourage their students to ask more questions, motivate deeper intellectual thinking, and facilitate student- 
to-student engagement. The instructor would also have an understanding of how well he is going to provide the class with the anticipated subject.

- A dramatization method, a non-verbal communication tool, is used quite seldom by both English and Chinese students.

- As opposed to Chinese teachers, English teachers emphasize daily newspaper reading to promote student awareness and to develop their expression and reading abilities.

- A successful behavioral adjustment method inside the classroom also involves incentives and reduced usage of punishment methods in both English and Chinese classrooms, which appears to build a sense of accomplishment and success within students and therefore motivates them to be more active.

- The findings of the study suggest that when employed in the classroom, humor may be an effective method. It is used as an important teaching technique in the class for both English and Chinese teachers to develop familiarity with the students.

This analysis demonstrated the effectiveness of teaching methods which instructors in this study regarded as a joint task, by means of hopes that mutually the learner and the instructor would lead to their progress (Bidabadi 2016). In general, teachers are acknowledged to play an essential role in supplying learners with the mastery, command, and ability to talk, write, hear and interpret in a superior manner (Arkoudis, 2003). On the other hand, Goodwyn \& Findlay (2003) says that all teachers are interested in effective teaching. Students can be unable since teachers of their subjects' material cannot help them grasp academic concepts in their language. The best teaching helps students to encourage and inspire them to improve by putting them in a position where their existing paradigm does not function and where they see themselves as authors of answers and agents of progress (Horta \& Shen, 2020). That means students address problems that matter to them. In addition, they claimed that most developing countries were seeking to adopt modern instructional techniques, like student-centered active strategies, project-based and problem-based curriculum methodologies (Anderson, 2012). There is now strong empirical proof that good learning mechanisms centered on two areas: (a) skill growth, including such problem-solving and analytical thinking, (b) lead to the applicant's potential to complete the program (Braxton, Jones, Hirschy, \& Hartkey, 2008). 
The results were focused on the data gathered by questionnaires.

\subsection{Conclusion}

The results of a detailed review and evaluation of the findings indicate that the purpose of the survey was to demonstrate at the institutional level in Pakistan the status of Chinese and English language teaching with regards to the implementation of their pedagogical skills, such as teaching strategies and teaching methods. The study shows that Chinese students were found to be passive learners. However, their progress in learning a foreign language is less or more a reflection of the methods of instruction that may have resulted from an overemphasis on the completion of the program within the stated duration, along with less motivation from the instructors. On the other side, English students have shown themselves to be active students when they engage with the program, take part in lectures, and communicate with each other. There is no sufficient training technique in the Chinese classroom that needs to be implemented to attain the students ' communication skills. The study suggests that teachers who teach Chinese at the institutional level require encouragement to use different styles of teaching methods to develop young learners ' language skills. Practiced training methods may be seen to be more appropriate for teaching English relative to Chinese.

\subsection{Recommendations}

Based on the analysis, the suggestions are rendered for the numerous sectors involved in the Chinese language teaching phase at the institutional level in Punjab (Pakistan). (1) Build a safe atmosphere, allow students to share diverse viewpoints, and 'think clearly.' Get to know the students and their expertise and experiences. (2) Various instructional approaches and strategies, such as student involvement, peer activity, community chat, can be used to enhance student involvement in Chinese classrooms. (3) The basic need for a classroom in the context of technology-based audiovisual assistance in Chinese classrooms must be rendered accessible to increase the success of teachers and students. (4) Both English and Chinese teachers used dramatization technique in their class because, through dramatization, consequently, the students in the contemporary institution can approach pleasantly and inductively the cultural world, the values, the standards, and the ideals transmitted by such works, acquiring a unique cultural consciousness, which will help them afterward to become persons with common collective memory. (5) Furthermore, the studies may be conducted to find the 
best approach to resolve the poor areas of teaching methods and teaching strategies in Chinese and English language teachers, especially in Pakistani academic settings.

\section{References:}

Abid, M., \& Ashfaq, A. (2015). CPEC: Challenges and opportunities for Pakistan. Journal of Pakistan Vision, 16(2), 142-169.

Ali, A. (2015). China Pakistan Economic Corridor (CPEC): Prospects and challenges for regional integration. International Journal of Social Sciences and Humanity Studies, $7(1), 1-15$.

Ali, Y., Rasheed, Z., Muhammad, N., \& Yousaf, S. (2018). Energy optimization in the wake of China Pakistan Economic Corridor (CPEC). Journal of Control and Decision, $5(2), 129-147$.

Anderson, A. (2012). The European project semester: A useful teaching method in engineering education project approaches to learning in engineering education. Journal of Engineering Education, 8, 15-28.

Arkoudis, S. (2003). Teaching English as a second language in science classes: Incommensurate epistemologies?. Language and Education, 17(3), 161-173.

Barr, R. B., \& Tagg, J. (1995). From teaching to learning-A new paradigm for undergraduate education. Change: The Magazine of Higher Learning, 27(6), 12-26.

Bidabadi, N. S., Isfahani, A. N., Rouhollahi, A., \& Khalili, R. (2016). Effective teaching methods in higher education: requirements and barriers. Journal of Advances in Medical Education \& Professionalism, 4(4), 170.

Braxton, J. M., Jones, W. A., Hirschy, A. S., \& Hartley III, H. V. (2008). The role of active learning in college student persistence. New Directions for Teaching and learning, 208(115), 71-83.

Canagarajah, S. (2013). Translingual practice: Global Englishes and cosmopolitan relations. London, New York: Routledge.

Fauziati, E. (2010). Teaching English as a foreign language (TEFL). International Journal on Studies in English Language and Literature, 9(1), 5-12.

Gil, J. (2011). A comparison of the global status of English and Chinese: towards anew global language?. English Today, 27(1), 52. 
Goodwyn, A., \& Findlay, K. (2003). ICT and subject literacies: a study of the relationship between ICT and subject literacies in the secondary school. ICT Research Bursaries, 26.

Khan, H. I. (2011). University students' attitudes towards the status of English in Pakistan. SPELT Quarterly, 26(3), 16-26.

Malone, S. (2007, September). Mother tongue-based multilingual education: Implications for education policy. In Seminar on Education Policy and the Right to Education: Towards More Equitable Outcomes for South Asia's Children (2007 Kathmandu).

Mastin, L. (2011). English as a global language: The history of English. Retrieved from: http://www.thehistoryofenglish.com/issues_global.html, March 16, 2018.

Mesthrie, R., \& Bhatt, R. M. (2008). World Englishes: The study of new linguistic varieties. Cambridge University Press.

Paik, J. (2009). " Learning English, Imagining Global": The Narratives of Early English Education Experiences in South Korea. International Journal of Learning, 15(10), 71-78.

Siddiqui, S. (2017). CPEC investment pushed from $\$ 55$ b to $\$ 62$ b. The Express Tribune, 12(4), 1-2.

Simons, G. F., \& Fennig, C. D. (2018). Ethnologue: Languages of the world, twenty. Dallas, Texas: SIL International. Online version: http://www. ethnologue. com Accessed, 26(12), 2018.

Xinhua News Agency. (2018). Chinese language proficiency test becoming popular in Mexico. China.org.cn. Retrieved from http://www.china.org.cn/learning_chinese/news/2011-. 